\title{
Effect of English Language Competency on the Job Satisfaction and Motivation of Teacher Educators: A Narrative Analysis
}

\author{
Zafarullah Sahito \\ School of Applied Educational Science and Teacher Education, Philosophical Faculty, University of Eastern Finland, \\ Joensuu, Finland; \\ IBA University, Airport Road, Sukkur, Sindh, Pakistan \\ Pertti Vaisanen \\ School of Applied Educational Science and Teacher Education, Philosophical Faculty, University of Eastern Finland, \\ Joensuu, Finland
}

\begin{abstract}
This research study was designed to explore the English language competency of teacher educators and its effect on their job satisfaction and motivation in order to maintain their position at their departments of Education at Universities of Sindh province of Pakistan. As, languages are generally taught and assessed in terms of four skills such as listening, speaking, reading, and writing. Where listening and reading are known as receptive skills while speaking and writing as productive skills, which are directly concerned and connected with the cognitive development of the teachers educators and its proper utilization to become satisfied and motivated faculty members. The data was collected and analysed through narrative analysis technique, the qualitative research design and method. The findings of this article would be found suitable, reliable, strong resource and a rich addition in to the existing literature, which provides a suitable insight to all stakeholders to understand the real position and phenomenon of language competency and its effects.
\end{abstract}

Index Terms-English language competency, job satisfaction and motivation, narrative analysis, teacher educators

\section{INTRODUCTION}

Educational institutions are considered the social institutions, which provide the conducive environment to its concerned inhabitant to learn all those things, which keep them up to date in order to face, accept, fulfill, meet and get success over the challenges of the present era. In conducive environment, the inhabitants learn knowledge, skills and their application well and properly to save themselves, the people, their language and the culture. In this regards, universities and higher education institutes have more responsibilities than other institutions such as schools, colleges, vocational institutions, etc. to do research on the emerging topics, issues and problems and explore their authentic solutions to maintain peace and security among the lives of the people of the country and globe. History witnesses that the university teachers and researchers worked hard to invent and innovate all things, known as the science and technology. As, we all know the modern automobiles, electronic items, digital items, etc. have great value in our lives. Because, they made human life easy and comfortable through minimizing the distances among the people of the world and make world as a global village to reach everywhere within a minimum time period. University teachers and researchers work efficiently, especially in the field of science and technology, when they know, what is going on in the modern era and what is the modern field to work well. These all things can be known through a suitable and good communication with people, literature and the systems, which can be possibly done in the same language of the instruction. The language of the medium of instruction of the universities of the world with especial reference to research is English, in which the important literature is available. Teachers have a great responsibility to teach and speak English language well in their classroom in order to motivate their selves, colleagues, students and staff to get success and achievement, as motivation is one of the variables that determine foreign-language achievement (Njadat, 1998). Because, people are motivated in various ways and means that suits the majority of teachers, students, educational administrators, and education system (Kocabas, 2009) to achieve the goals of learning English as the second language and medium of instruction of higher education institutions. Therefore, the factors affecting motivation levels of teachers can be understood by interpreting the behaviors of individuals identified and explored through various researches (Celtek, 2004). English is the language of science and technology, and other all field of studies throughout the universities and research institutions of the world. The usage of English as a foreign language in different countries increased due to the large number of immigrants, high need and attitude of students and women, interest to learn foreign language and the requirement to use technology to accomplish unskilled jobs (Dweik \& Awajan, 2013). 


\section{ENGLish LANGUAGE COMPETENCY, Job SATiSfaCtion AND Motivation}

Competency means power, ability, capacity and capability; may be physical, mental, financial or legal to perform well to meet the need, demands, requirements, and requests to respond the challenge to achieve personal, professional and organisational goals through fulfilling the duties and responsibilities. Competency and proficiency used frequently and interchangeably to show the language skills of a person with special reference to work efficiently to deal with all matters especially by teachers in classroom, where fluency and language competence are generally recognized it. As a limited English proficient student, comes from a non-English language background to have a sufficient difficulty in speaking, reading, writing, and understanding the English language. A fully English proficient student is able to use English to ask questions; to listen and understand teachers; read and understand reading materials; take out different ideas, understand, relate and test them in their life; and challenge what is being asked in the classroom. Teachers and students interest can be created through some rewards and support, which can be started within or from inside of the core of the heart. As, Ministry of Education (MoE), school principals, English language supervisors, teachers, colleagues and students do not motivate the English language teachers in Jordanian public secondary schools but they are motivated because of likeness to their jobs that gives them security for their families and prestigious to be confident to have efficiency of English language (Dweik, et al., 2013). Because, English was taught in Jordanian schools as a foreign language due to its importance to communicate effectively and efficiently in all fields throughout the world (Cook, 2003; Momen, 2009; Schmit, 2002).

Teachers' job satisfaction and motivation is the important factor that leads towards the classroom effectiveness and school improvement, consists on the teachers' desire to participate actively in the educational process and procedure to benefit their students, parents and society (Ofoegbu, 2004). As, the term effective itself is complex and controversial, as it revolves around the what, whom, when, where and why questions (Rogers, 2011). Here the question is how teachers would be benefit providers and the answer is when they have a good grip over the knowledge, pedagogy and skills that can be done through reading good and authentic materials, learning from the readings, and finally applying them as per situation, which all can be achieved through the competency of English language. Because, the competency helps the teachers to read well, to learn high, and apply properly and authentically in order to get successful results. Therefore, it is an important concern for educational leaders and managers to improve, increase and enhance the teachers' motivation that effects the students' motivation to learn well and achieve good grades. It is also important for the improvement of educational reforms and progressive legislation, to make effective policies through proper implementation of rules and regulation to create the conducive environment where teachers' become satisfied through fulfillment of their duties and responsibilities (De-Jesus \& Lens, 2005).

Teachers' motivation became a critical factor and it determines a list of variables such as the existence of enabling the environment and the equipments. It links with, how teachers feel about the dealing and treatment given them in their organisations; and how they perceive about their own working and living conditions (Davidson, 2007). As, done in Jordan such as many efforts were taken by all stakeholders to improve the process of education, still the majority of teachers in Jordan are not motivated to improve their English language skills to teach in their classroom. The improvement of the competence and commitment is the most important determinant of learning outcomes, can be achieved through the importance of English language skills of teachers played in the process of education in Jordan (AlAli \& Al-Saleem, 2009; Njadat, 1998). We all know that all dealings at international level are done in English, especially the talks, discussions, memorandums, agreements, etc. However, the things and the systems can be managed to work on the training programs to improve the English language competency of the teachers through the consideration of their role and responsibilities to bring the radical reforms in the system of education. As, the role of teacher would be ensured and must be recognized, understood, and taken into account for effectiveness of education. Their rights must be realized in order to secure and strengthen their own commitment to achieve the quality education for all (Davidson, 2007), which can be easily and possibly achieved through increasing the competencies of the teachers.

English language speaking teachers' motivation revolves around the intrinsic and extrinsic factors such as internal desire to teach; and a long term job stability, autonomy to choose methods and materials for classroom teaching, positive working relationships, good communication, community and self-realizations for overall success (Praver, et al., 2008). The intrinsic aspect of Greek teachers was found more satisfied and more motivated than the extrinsic motivational aspect. The chronological dimension plays an important role in the development and motivation of teachers as they think and take teaching as a profession has a lifelong engagement (Gheralis, 2003). One more study identified the private school teachers more dissatisfied than their counterparts in public schools, as there were three major factors influencing their motivation and occupational choices such as demographic traits, intrinsic factors related to their inner feelings about job, and extrinsic factors related to the objective characteristics of the work itself (Wang, 2005). The motivation level of the (300) private schools teachers in Amman was found high and their performance was found high from the (100) principals' point of view. As it is assumed that, the school administration is responsible of the motivation of teachers (Diamantes, 2004; Kocabas \& Karakose, 2002) and vice versa. The demotivation experience was found between Saudi Arabian and non-Saudi Arabian English language teachers, due to the conflict between commitment and the inadequacies of the educational institutions, depending on the administration of institutions where they are working (Shoaib, 2004). The $(61 \%)$ of the English language speaking teachers found motivated by their students, to have a dialogue connection between them through creating a high feeling of efficacy and the sense of 
accomplishment in classroom (Praver, et al., 2008; Scott, Cox \& Dinham, 1999). The (72\%) teachers found motivated because it is prestigious for them to be an English language teacher, as English language is the language of communication all over the world. It is the second and official language in most of countries and taught as a foreign language because of its importance. It begins to teach from the first grade in most of the public and private schools in many countries. Every person cannot like and get an opportunity to work in the private sector because most of the people prefer the public sector institutions to teach for the purpose of job safety and security, and attractive salary that is available only in the public rather than the private sectors. As teachers' motivation is concerned with the demographic traits, inner feelings about job, and the work itself (Davidson, 2007; Gheralis, 2003; Wang, 2005). The (74\%) English language teachers found motivated because they like their jobs to become more active, affective, and creative to deliver more to their students (Hussin, 2000; Ofoegbu, 2004; Praver \& Oga-Baldwin, 2008; Wang, 2005).

\section{METHODOLOGY}

\section{A. Research Method and Procedure}

The qualitative research design was employed, which revolves around philosophical assumptions of epistemology and ontology (Crotty, 1998), and supported by the interpretivism and epistemological constructionism means the reality is multiple and the knowledge is constructed and a subjective entity in nature (Creswell, 2009) respectively. The data was collected through semi-structured interviews from the recruited sample of TEs. The heads of departments were approached to get permission to collect data from the TEs working at their departments. The short description and explanation of the concept or the topic was designed, managed and published in written form, in order to share and discuss with the sample of TEs. After sharing and discussion, TEs were invited to share their life experiences about their English language competency, learning, professional development, success, job satisfaction and motivation throughout their services.

The narrative analysis was done for this study on the collected data, as narrative inquiry considered suitable to employ as an analysis tool in the fields of cognitive science, organisational studies, knowledge theory, sociology and education studies. It captures the human and personal dimensions of experience and consists of relationship between individual experience and cultural context (Clandinin \& Connelly 2000). The narrative analysis focused on content of stories and the meanings, depending on the philosophical position and considers as a window open towards the knowable reality, which is socially situated knowledge constructions, differences and texture of experienced (Polkinghorne, 1995). Where analysis means to covert the said dialogues or narratives in to the real meaning, occurred throughout the research process (Riessman, 2008), as the narrative analysis treats stories as a knowledge creator and constitutes the social reality of the narrator (Etherington, 2004), conducted with one's own (Etherington, 2006, 2000; Wosket, 1999) or with other clients (Etherington, 2007) or people. The importance and authenticity of narrative methods is define by Muylaert, Júnior, Gallo, Neto, and Reis (2014), as the narrative interviews method is a powerful and used by researchers who believe in summative type of studies to conduct. In this regards, the criteria of the phases of the narrative interview of Jovchelovich \& Bauer (2002), was followed to conduct the interviews of the TEs, consists of the phases such as preparation, initialization, main narration, questioning and small talk. Furthermore, the narrative method is an investigative resource in qualitative research, which is a traditional form of communication whose purpose is to serve the content in order to transmit the subjective experiences (Muylaert, et al., 2014). The perspective of the informant is best revealed their spontaneous language (Jovchelovich, et al., 2002), as the narrative implies the ownership position assumed by the writer, in the face of life and the problems of society.

The identity of interviewees and the interviews data was kept highly confidential (Shaw \& Gould, 2001). The qualitative research methods and techniques are suited betterly to define the meanings of the narrated sentences of the interviewees with their richness and genuineness of the spoken words and sentences (Flick, 1998; Strauss \& Corbin, 1998). However, the nicknames were assigned them to use with their narratives in data analysis portion. The criteria for judgement of the quality the list of characterizing traits was used (Sparkes \& Smith, 2009, 2014) followed by the criteria of Tracy (2010).

\section{B. Participants}

Forty participants were recruited for the study through multiple perspectives and the snowball and purposive sampling techniques in order to collect the in-depth, true and real data. As, the number of research sample may be several and ranging from 1 or 2 to 30 or 40, depending on the need to report details properly about them (Creswell, 2012). The friends, means the TEs who are working in different teacher education departments (TED) were requested to be the participant of the study and suggest their friends to involve them in the study as interviewee. With the passage of time, the required sample for study was arranged and their time for interview was managed at different departments and universities in Sindh, the province of Pakistan.

\section{RESUlts}

The interview were conducted from forty TEs on the topic but eighteen were found very much relevant and impressive in their stories. They expressed their life experiences very well with high attraction and their reasons were 
found highly authentic to quote here as narratives. The nicknames were given to the eighteen TEs at the place of their original names in order to keep their names confidential as per agreement, which was done with them before conducting interview from them. The important narratives were recorded and selected to use for the analysis of the study, are given here, with respect to the stories told by the TEs in their interview regarding their English language competency, job satisfaction and motivation.

The interview was conducted with Meer, working as assistant professor and having a more than twelve years teaching experience at school, college and university. He commented during his story as "English language competency really play a great role to get good job on merit basis in the country like Pakistan, which was increased, improved and enhanced by self-efforts, self-interest and hard work. It keeps me always confident to complete my assignments, which make me happy and motivate to work more with efficiency to progress". The TE serves as high school teacher and then lecturer in college and presently as faculty member in TED at university. He got all the positions through different testing systems, public service commissions and selection board purely on merit basis. As, he expressed that he belongs to a middle class family and the elder son of their parents to have great responsibility to support their younger brothers and sisters to get good education for their survival. His success is remarkable due to having a good knowledge of his subject and the competency of English. His success made him a financially sound to deal with all the expenses of his family, which affects positively on his younger brothers and sisters. This story focuses on the theme that one good job not only make one-person financially sound but it also increases the economic and social status of the family as whole.

The interview was conducted with Nawaz, who is working as lecture at his department. He told regarding his competency through his story and shared one more reason such as "My English language competency is strong because I got my whole education in reputable private English medium schools and colleges. Where everything is taught practically and provides a high opportunity of practice through conducting co-curricular activities, debate, speeches, poetry and declamation context, which became helpful to increase the English language competency and confidence”. The discussion of Nawaz reveals that he got his whole education since school to university in English medium institutions. Where he learned English very well and with the passage of time he improved, and enhanced his vocabulary, writing and spoken skills. It seemed that curricular and co-curricular activities played an important role to groom him well, especially through discussions, debate, speech, poetry and declamation context conducted at a wide range in reputable private schools in Pakistan. It is revealed from the story that co-curricular activities provide a good opportunity to participant students and teachers to improve their competency level, which increase the confidence to deal all things well to get satisfaction in their student and professional life. Because, the hard work, skill development and satisfaction of students' life directly effects on the professional life of the individual, which may increase through financial and professional achievement and success.

A TE Faheem, who is working as lecture, shared his story regarding his competency in English language and satisfaction with few reasons such as "During my higher studies I used to start to listen to songs and videos in English with my friends, those were very good at speaking English. Continuously listening songs and lectures, watching videos and films my competency was increasing. It was further improved when I started to speak in English in my class during lectures to ask questions from my teachers". The discussion of story of Faheem reveals that he got his English language skills improved through listening English songs and watching English movies with their classmates and friends. Because, during and after listening songs and watching movies they discuss many sentences with their friends and get further explanation from their group. The all members of group participated actively in discussion, which increase their spoken and listening skills. This skill development increased their confidence level and make them motivate to speak in their classes at the front of their classmates and teachers, even though they started to participate in class discussions actively and ask questions from their teachers about their subject during lectures. Asking questions from teachers make them able to understand their contents well and increase their knowledge about their subjects, which help them to prepare well for their examination, to bring good grades and marks for bright future endeavors, achievement and success.

The story of Shaheen, who is working as lecture, shared her story that she got competency in English language and satisfaction as "During my university studies time I used to read the Dawn newspaper on daily basis, which was very difficult work for me in starting. Initially I used to read one to three paragraphs and try to understand their meaning from Oxford dictionary. However, with the passage of time, my habit was developed and I started to enjoy learning new words from newspaper and dictionary. This continuous practice of three to four years made me able to read, write and speak very well". The story reveals that for the improvement of her skills, she started to read and try to understand the description of the paragraphs of reputable English newspaper. Initially it was tough activity for her but she got it very much fruitful after continuation and hard work, especially when she felt that with the activity she is getting good results and achieving her aims and objectives of her studies, in classroom and examination. Because, with the passage of time it was became her habit to read the newspaper and understand the meaning of new words to know the description of the paragraph properly. The continuous practice make her able to read, understand, write and speak very well at every platform with educators, teachers and researchers, to share her views and ideas and learn from others about the emerging areas of teaching and research.

The story of Siddiqa, working as an assistant professor, revealed about her competency in English language, satisfaction and motivation such as "My English language competency is excellent. I am M.A in English literature. My 
degree helped me to learn English language through reading many books and attending lectures of highly qualified faculty at my department during my degree. Preparation for papers also enhanced my language competency". The story of Siddiqa reveals that her English language skills are excellent because she did her masters in English literature. She did work hard during her student life at university, as to get M.A in English is very much tough job, especially in first class. She read many books related to her subjects during her degree, made many power point presentations and delivered in her class, which gave her a strong insight to learn good English skills that help her to prove herself as a competent student and teacher after completion of degree and getting job. She was attending regularly the lectures of her qualified professor during her studies, which were remained the main inspiration for her to improve and enhance her English language skills. Because, the majority of her teachers were very social enough to appreciate their students to learn well, which made the students successful, qualified and motivated to become teachers at university level.

The story of an assistant professor Shahnawaz revealed about his English language competency, satisfaction and motivation as "I learnt English language at different tuition centers. Especially English language centers like American cultural center and many other centers, running by private owners at my hometown. I attended language courses and completed all levels of the different course taught by different people. Finally, I had a good grip over the speaking, reading, listening and writing skills". The story of Shahnawaz revealed that his English language skills are excellent because he used to attend English language tuition centers from his school life. Where he used to learn and did a high level of practice during his stay of seven years. He attended many language courses, as there were many courses and levels for different purposes to improve different skills. Like spoken English courses and levels, except this there were different courses and level for reading, writing and listening. With the passage of time, as he completed different courses and levels, he acquired a good grip over the skills and finally got good competency on English language skills. His competency help him a lot to prepare for class lectures, to face his students' questions and reply them soundly to make them happy and satisfy, because the students' satisfaction and happiness make teacher happy, satisfied and motivated.

The story of Ali revealed about his English language competency, satisfaction and motivation, as "My English language skills are excellent. Before university teaching I was teaching at reputable English medium schools for eight years. Where I used to teach social studies and social science subjects. The regular preparation of subject contents to teach, made my language skills sharpen and enhanced. The environment of these schools was conducive to speak English frequently all the time". The story of Ali revealed that his English language skills became excellent because he used to work at English medium schools for eight years before university teaching. He was teaching social studies and social science at schools, which needs more preparation to share the concept of different ideas, related the physical, psychological and ethical issues and philosophies of the community, society and the world. For the regular preparation of different topics, teachers have to read many books, magazines and newspapers to have a suitable knowledge and good grip over the content of the topic, which provide an authentic and interactive opportunity to have high-class practice for a long period of time. The high-class practice for a long time sharpened and enhanced the English language skills and competency of the teachers, which make them active to work smoothly, quickly and accurately to get good confidence and compete everywhere at different plate forms to get high success and achievement.

The story of Khaliq revealed about his English language competency, satisfaction and motivation as "My English language skills are excellent especially spoken skills. My parents speak English at our home before my birth. The available English speaking opportunity and environment help me a lot to speak well. My English language competency makes me confident to deal my all matters in professional life easily. The confidence makes me satisfied and increase my interest to work well". The story of Khaliq was found interesting and seemed an involvement and effect of parents on their children. It revealed that his English language skills became excellent because of his parents, who were used to speak English language frequently at their home before his birth. Because, his father was a professor and did his doctoral degree from a developed country and his mother was a medical doctor. They did love marriage and always remained very happy in their life and sharing many common characteristics such as both have good job and earnings, speak good English, help to each other and highly social in their life to support their family members and relatives. His English language skills are excellent, because he learnt to speak from his parents since his childhood. The home environment and the support of parents make him able to learn good English language skills in order to be confident, which make him satisfied and it increases his interest to work well and interact confidently.

The story of Ahmed revealed about his English language competency, satisfaction and motivation, as "I was good at English skills. After graduating, when I was searching job and doing preparation for commission and selection board, I referred many books, newspapers, audios and videos to learn many topics as I can. The most of the materials were in English, so continuous reading and preparation for two to three years sharp and enhance my English language skills, which made me satisfied and motivate to work more. Because, hard work makes you visible at the front of all and between the competitors". The story was found interesting depending on help self-concept, which was started after his graduation. During his job search, he gone through many books, newspapers, video and audio lectures to get prepared for written test and then interview. He worked hard for three years continuously and finally got success in the shape of job, during this period, he learnt and improved his English language skills through reading of different literature. His skills always support him to read more to learn more through hard working, because hard work made him visible at the front of others, especially between the competitors and the heads of the department, institute and organisation. 
The story of Abdul revealed about his English language competency, satisfaction and motivation as "I increased and enhanced my English language skills through giving home tuitions to different students of different classes since my student life. Most of home tuitioners were studying at good schools whose English language skills were good. Through teaching learning process and having very social interaction with them, I got good practice opportunity to improve my language skills to make satisfy myself and others". The story of Abdul revolves around having good practice and application of his knowledge and skills. His story reveals about his activities of home tuitions from his student life. He used to giving home tuitions to many students in a day and teach different subjects to them, especially the English grammar and text. During his tuition time, he used to speak in English with his students, which increased, enhanced and updated his English language skills to deal with his students and their parents. He remained in this practice for many years and most of his students remained satisfied with him due to his good English language skills. Majority of students were belonging to reputable English medium schools and having social interaction with them during discussing the things, which was found a great and important activity of his success of improving the language skills to make satisfy himself and others especially the students and their parents.

The story of Sania revealed about his English language competency, satisfaction and motivation as "My English language skills are good to teach confidently. I started teaching twelve years ago from a small English medium school. Then high school and now at university level. As I was moving from one level to another, my experience, pedagogy, attitude, dealing and English language skills were improving day by day. Finally, all my charactertics made me confident and satisfied to teach well and make my students satisfied". The story of Sania highlights that she has good English language skills, which make her bold to teach confidently. As, she started her teaching career from a small English medium school to teach small kids and then promoted to high school to teach adolescents and finally appointed at university level. During this whole process of her teaching profession, she learnt a lot with her experience such as pedagogy, attitude, dealing with students and English language skills, which became the reason of her appreciation at all levels and platforms. Because she considered her competencies as characteristics, which can be seen by every stakeholder inside and outside of the organisation. The existing characteristics among teachers make them responsible, satisfied and motivated, to work well, to maintain their position and respect in their concerned department and institute.

The story of Zahid revealed about his English language competency, satisfaction and motivation as "To conduct the training sessions for teachers is one of the main responsibility of university teachers or teacher educators. I conducted many training sessions for teachers and acquired great positive response from them. This is done only due to refer the materials in English, which was done due to having good English language skills. Receiving positive response made me always happy and satisfied". The story of Zahid focuses on the good English language skills, which have been improved due to referring of different materials such as books, reports, training manuals, video and audio lectures. As we know, the majority of the resources are available in English language, so continue searching, reading, understanding, making presentation and presenting them during training sessions gave him a good opportunity and ground for practice. The continue practice made him able to have good language skills, which attract trainee to like training programmes and respect trainers to get good advices all the time during and after training sessions. The positive response receiving from trainee makes trainers happy and satisfied, which is a great appreciation to work further well in future.

The story of Zafeer revealed that, "My English language skills help me to get work done. Especially to write research papers. For writing research papers two things are necessary, one primary data and literature. Both things can be done well through reading the concerned material. Papers are to be published in good research journals through reading and understanding their scope and instructions. Here good English language skills help me to read, write and submit the research paper to any journal for publication. It makes me confident and happy to work hard for further publications in order to get respect and promotion in my organisation". The story focuses on his English language skills, which help him to complete his work, as the main responsibilities of university teachers are teaching, research and trainings. The focus is on writing of research papers, which consists of primary data, reading and reviewing of literature, which can be done only through good English language skills. In all process, his good English language skills help him a lot to read, understand well and then act as per instructions to get success in publishing the research papers in reputable journals. Because, his skills give him confident to write and submit the research papers for publication.

The story of Zaheer revealed as "My English language skills help me to present conference paper in any national and international conferences; to answer well the questions asked by the audiences and after presentation, meeting with the research community and exchange of ideas. Making of personal reputation and for further research in collaboration with other researchers and institutes. This whole process makes me connected with other researchers and increase my confidence to discuss with them about the current issues for new research studies. It makes me happy and satisfied teacher educator". The story revealed that his English language skills help him to write paper and present them in national and international conferences. English language competency makes him confident to take questions from the audience and answer them well with suitable findings and quotations. During conferences, he get a good chance to interact well with other researchers and make a good and strong connection and collaboration with them to work together in future. This positive interaction brings different researchers of the world in to a binding working and research relations to work on new projects within a group through multidimensional approaches. Interaction with other renowned researchers of the world provides a great opportunity to have new topics for research, which change the mindset of the researchers to view the world in different direction that leads them towards the innovation and invention. 
The story of Azhar revealed as "My English language skills help me to present and discuss the new ideas in the Think-Tank meetings at my department, institute and organisation. Most of the time, the whole conversation is done in English. My confidence increased with the passage of time due to spoken skills, which make me satisfied and motivated member of the committee". The story highlighted that because of his English language skills he became the member of the think-tank committee at his institution. His language skills help him to present the new ideas regarding new assignments, activities and future planning. During the meetings, he actively discusses and exchange the ideas on different topics, assignments and future endeavors to grow and develop the institute. The medium of instruction of the meeting is English and most of the items are discussed and approved in English, here his skills helped him in real sense to deal with all matters well.

The story of Niaz revealed as "Based on my English language skills, I have been selected a member of different committees in my department, institute and organisation. Where my main responsibility to write, review and edit the different documents. Most of the time, my colleagues used to come to discuss their problems and issues in order to get suitable suggestions". The story of Niaz highlighted that based on his English language skills he selected as the member of different committees in his department, institution and organisation. The writing, reviewing and editing of different documents such as minutes of meeting, circulars, letters, etc. are the main responsibility of him. Due to this responsibility, his colleagues, faculty members and students used to come to him to get advice to execute their matters to get good results. Because, the procedures, rules, regulations and laws are discussed and implemented on regularly basis through these committees. Listening the matters of different people, discussing them in detail and finally suggesting them in the proper way give me immense pleasure to become satisfied and motivated individual of the organisation to work for the betterment of the organisation and the employees.

The story of Kashifa revealed as "Due to my competency and expertise in English language, I have been selected a member of senate by my faculty, which is among the main decision making bodies at universities. My main responsibility is to work as a secretary to write, finalised and publish minutes of the meeting after approval of competent authority". The story of Kashifa highlighted her main achievements based on her English language skills such as she selected as the member of senate, which is one of the highest decision body working at independent institutions and universities. She is deputed as the secretary of the body to keep all records safe for further use and progress of the organisation and welfare of the employees. Because, the procedures, rules, regulations, laws and budgets are discussed and finalised in this body belonging to future growth and development of the organisation. It is lengthy and difficult process to become the member of senate or syndicate, and especially to depute as the secretary of the committee.

The story of Surfraz revealed as "Having degree, competency and expertise in English language, I have been selected a member of board of studies at department, faculty, university and national level organisation. Especially at higher education commission (HEC), level as research supervisor and curriculum committee member". The story of Surfraz highlighted his achievements based on his degree, expertise and competency in English language. He has been selected an active member of board of studies at department, faculty, university and national level to participate, review and update the curriculum, syllabus and outlines. To become the member of higher education commission (HEC) curriculum review committee is really a great opportunity for teacher, his institutions and university, because universities play a vital role to conduct research and teach research based item to students. He is also an approved supervisor of HEC, which is a matter of proud for teacher and his organisation. These all achievements make him proud, happy, satisfied and motivated TE to focus actively on his work.

\section{DISCUSSION}

In this article, an attempt has been made to highlight and interpret the most common narratives used by eighteen TEs during telling their story in interview. There narratives and stories were fully focused their English language competencies, job satisfaction and motivation. We have used those narratives, which were aspired and appealed us to reflect their meaning, possible function and detailed description about the said topic. The data revealed that there are number of guiding metaphors available in the stories of the TEs, which made them successful, satisfied and motivated to live a peaceful life at their department and organisation. It was also revealed from the data that the peaceful life at department and organisation have a great positive effect on personal and familial life of the TEs, which depended on the knowledge, skills, competency, expertise, experience and behavior of TEs.

The main and the important statement in the narratives of TEs about English language competency, job satisfaction and motivation were self-interest, self-efforts and hard work, which support to gain high competency, as the reality is that the majority of teachers hardly know how to speak English language, but the responsibility is given them to teach in it (Shamim, 2008). Like English teachers in government institutions, teach in Urdu or in local languages because their own competence and confidence in English is poor (Coleman, 2010). Because, they concentrate more on translation and grammatical methods and aspects of language as compared to oral competency (Ghafoor, 1998), and they do not see any difference between the teaching of English and other subjects like Social Studies or History (Nawab, 2012). The quantity and quality of resources such as human resources allocated for teaching and learning process (Shamim, 2008), especially a number of private schools and institutes offer English medium education (Andrabi, et al., 2007). Even though that claim is not be fulfilled in reality as $21 \%$ cases of teachers from 89 countries mentioned that they were not 
qualified to teach English or in English in their institutions (Emery, 2012). School system, private schools, tuition centers, home tuition, parents' language skills and home environment effect positively to support their children to learn skills and competency. As, family members play a key role in the skill development and career choice of female teachers in Pakistan through parents' encouragement to attend teacher-training degree programs (Barrs, 2005; Oplatka, 2007) held at universities and colleges of education. The people who became teachers due to a lack of other opportunities and no personal choice were likely to have a lower level of commitment and dedication to teaching profession (Hedges, 2002) than those who choose this profession as their choice and always try to learn new things and improve their language skills too. The $(73 \%)$ teachers joined this profession by chance because of having no other option for jobs while, only $9 \%$ teachers joined this profession with their personal interest. The main idea of becoming a teacher should be B.Ed. or M.Ed., and have the ability to teach and speak English (Malik, 2008). As the public school teacher having a Master's degree other than English interested in learning English, therefore she opted to teach in English while the other teachers of private institute having Master's degree in English with no personal interest in teaching. Because she became a teacher by chance and felt that, her Master's degree has no impact to support her in classroom instruction (Bashiruddin, 2009). Skill development can be improved through increasing listening and use of newspaper and dictionaries. As, it is explored that 52\% students can communicate confidently, as they possessed good English language listening skills and they claimed no problem in reading, and remained neutral to comment about their capabilities to write in English language (Ibrahim, Hassali, Saleem, Haq, Khan, \& Aljadhey, 2013). Preparation for tests and interviews to get good job was found an important aspect of improving skills. As, the unemployment was increased among Malaysian people due to their poor competency of English language (Abdullah et al., 2010; Heng \& Tan, 2006; Lim et al., 2008). Because of announcement of the importance of English language, which was made the medium of instruction in all higher educational institutes (Heng \& Tan, 2006) to meet the economic and technological development. Initially, the majority of university graduates felt uncomfortable, to use English language in their day-to-day communication and conversation (Musa et al., 2012). Especially when they face high competition in their profession at globalisation level to enhance and improve the sale of products and patient-oriented services that requires to use the English language proficiently for professional purposes and business success (Abdullah et al., 2010).

Based on the competencies of TEs, they became the member of different committees and decision-making bodies such as senate and syndicate and board of studies and national committee of curriculum and syllabus. The English language competency and teaching can be improved through increase of relevant qualifications, modifying the pre-service and in-service training mechanisms, and making transparent and meritorious hiring practices of the teachers and TEs (Bashiruddin, et al., 2014). The essential role of competent teachers and TEs is to work for the upgradation of the general well-being and life success of their students to possess the basic-critical thinking, problem solving and collaboration to deal with the needs, demands and requirements of $21^{\text {st }}$ century (Durlak, Weissberg, Dymnicki, Taylor \& Schellinger, 2011). Because, effective teaching revolves around four essential elements such as teaching, the process, students' learning and the product (Walls, 1999) and they possess twelve characteristics such as prepared for their work, positiveness, hold high expectations, creative, fair, display a personal touch, cultivate a sense of belonging, compassionate, have a sense of humor, respect students, forgiving and admit mistakes (Walker, 2008). Generally, the effective teachers may possess the characteristics such as positive, forgiving and compassionate to get their students to be more involved in learning (Walker, 2008). English language proficiency empowers the teachers and head teachers to make them elevate and confident to communicate well, especially in front of their subordinates. English proficiency and communication skills make them capable of communicating with the official orders and notifications from the concerned offices, as English is the official language of the country (Ali, Rabnawaz, Ali \& Ahmad, 2015).

\section{CONCLUSION}

Based on the findings of the collected data and its interpretation we conclude that the English language competency of TEs at higher education level in different universities increase the JSM of faculty members. The ELC has a power and energy, which create and infuse interest among the employees to get work done in a proper and authentic way to progress well at national and international level, especially to work hard for quality education. As, in the case of the quality and improvement of the standards of education in Pakistan, which have been expected to bring in to action in the national standards document (GOP, 2009). Then, it will have to provide relevant qualifications and trainings to the teachers to improve their English language and ICT skills, through emphasizing on pre-service teacher education, to foster the continuous professional development of teachers, to choose the proper, authentic and modern techniques required for $21^{\text {st }}$ century, through exploration and establishment of professional learning communities (Kennedy, 2005) and reflective conversations (Ashraf \& Rarieya, 2008). Because, the profiles of teachers in Pakistan were broadly studied, explored and it is found that the majority of the teachers are teaching in same stream, where they studied, without having any specialized degree and training to improve their English language competency. However, they are working as per instructions of administration to teach in English and English subject; and they came from those institutions where no written policies especially for hiring of teachers and subject-specialists existed (Bashiruddin, et al., 2014) to know about the duties and responsibilities of different positions especially of teachers, curriculum and medium of instructions to teach. 
Each employee's performance is important in an organisation that can be motivated through the application of Skinner's Reinforcement theory such as positive reinforcement, the most commonly used method to strengthen the one's behaviour based on consequences (Wei \& Yazdanifard, 2014). Employees who received their feedback, whether positive, negative, or corrective showed improved performance (Hinkin \& Schriesheim, 2004). Employees do any work well when they know the high level of motivation is available for them to do particular thing or work (Fagbohungbe $\&$ Longe, 2011). There is an important and pivotal role of rewards and punishment in behavioural psychology to motivate employees to work hard in order to achieve the required objectives in an organisation (Kohn, 2004). Because after rewarded for performances employees likely to perform better as employees feel appreciation and sense of belonging to organisation on acknowledgement from supervisors (Shiraz, Rashid \& Riaz, 2011). No or less appreciation on good performance diminished employees' effectiveness and reduced their satisfaction (Hinkin, et al., 2004), which effects the overall performance of organisation.

\section{REFERENCES}

[1] Abdullah, K.I., Rahman, A., \& Lina, N. (2010). Australian universities (online). Available at: http://www.deewr.gov.au/HigherEducation/Publications/Documents/Final_ReportGood_Practice_Principles.pdf. Accessed: $26^{\text {th }}$ March, 2012.

[2] Al- Ali \& Al- Saleem. (2009). High secondary stage teachers and their ability of processing educational research skills from their perspective in Mafraq governorate-Jordan. Journal of Human Sciences, 24, 1-34.

[3] Ali, M.Q., Rabnawaz, Ali, F., \& Ahmad, W. (2015). Role of English language proficiency for leadership qualities among head teachers. Journal of Policy Research, 1(2), 94-99. URL: http://rfh.org.pk/jur/magazine-category/jpr on 14.09.2017 at 5.30.

[4] Andrabi, T., Das, J., Khwaja, A.I., Vishwanath, T., \& Zajonc, T. (2007). Learning and Educational Achievements in Punjab Schools (LEAPS): Insights to inform the education policy debate. Washington DC: World Bank.

[5] Ashraf, H., \& Rarieya, J.F.A. (2008). Teacher development through reflective conversations-possibilities and tensions: A Pakistan case. Reflective Practice, 9(3), 269 - 279.

[6] Barrs, J. (2005). Factors contributed by community organisations to the motivation of teachers in rural Punjab, Pakistan, and implications for the quality of teaching. International Journal of Educational Development, 25(3), 333-48.

[7] Bashiruddin, A. (2009). Learning English and learning to teach English: The case of two teachers of English in Pakistan. In S. Mansoor, A. Sikandar, N. Hussain \& N. Ahsan (Eds.), Emerging Issues in TEFL: Challenges for South Asia. Karachi: Oxford University Press.

[8] Bashiruddin, A., \& Qayyum, R. (2014). Teachers of English in Pakistan: Profile and recommendations. NUML Journal of Critical Inquiry, 12(1), 1-19.

[9] Celtek, E. (2004). Motivation management. Business Force Industry Relations and Human Resource Magazine, 6(1), 56-60.

[10] Clandinin, D.J., \& Connelly, F.M. (2000). Narrative Inquiry: Experience and story in qualitative research. Published by JosseyBoss, John Wiley \& Sons, Inc., San Francisco.

[11] Coleman, H. (2010). Teaching and learning in Pakistan: The role of language in education. Leeds: British Council.

[12] Cook, G. (2003). Applied linguistics. London: Oxford University Press.

[13] Creswell, J.W. (2012). Educational research: planning, conducting, and evaluating quantitative and qualitative research, $4^{\text {th }}$ (ed.). Pearson Education, Inc., Boston, USA.

[14] Creswell, J.W. (2009). Research design: Qualitative, quantitative and mixed methods approaches, $3^{\text {rd }}$ (ed.). London, England: Sage Publications.

[15] Crotty, M. (1998). The foundations of social research: Meaning and perspective in the research process. London, England: Sage Publications.

[16] Davidson, E. (2007). The pivotal role of teacher motivation in Tanzanian education. The Educational Forum. Retrieved November 13 http://www.hakielimu.org/hakielimu/documents/document100pivotal_role_teacher_motivation_en.pdf.

[17] Diamantes, T. (2004). What principles think motivates teachers. Journal of Instructional Psychology, 12(4), 33-35.

[18] De-Jesus, S.N., \& Lens, W. (2005). An integrated model for the study of teacher motivation. Applied Psychology: An International Review, 54(1), 119-134.

[19] Durlak, J.A., Weissberg, R.P., Dymnicki, A.B., Taylor, R.D. \& Schellinger, K.B. (2011). The Impact of Enhancing Students' Social and Emotional Learning: A Meta-Analysis of School-Based Universal Interventions. Child Development, 82: 405-432. doi:10.1111/j.1467-8624.2010.01564.x.

[20] Dweik, P.B.S., \& Awajan, N.W. (2013). Factors that enhance English language teachers' motivation in Jordanian secondary schools. English Linguistics Research, 2(1), 33-42. doi:10.5430/elr.v2n1p33.

[21] Emery, H. (2012). A global study of primary English teachers' qualifications, training and career development. British Council, $69,12-08$.

[22] Etherington, K. (2007). Ethical research in reflexive relationships. Qualitative Inquiry, 13 (50), 599-616.

[23] Etherington, K. (2006). Chicken or egg? An exploration of the relationships between physical and psychological symptoms with a woman diagnosed with Tourette's syndrome. In Counselling and Psychotherapy Research, 6(2), 138-146.

[24] Etherington, K. (2004). Becoming a reflexive researcher: using ourselves in research. London: Jessica Kingsley.

[25] Etherington, K. (2000). Narrative approaches to working with adult male survivors of childhood sexual abuse. London: Jessica Kingsley.

[26] Flick, U. (1998). An introduction to qualitative research. London, England: Sage Publications.

[27] Fagbohungbe, B.O. \& Longe, S.O. (2011). An introductory psychology: Concepts and principles. Lagos: Kotleb consults.

[28] Ghafoor, A. (1998). Promoting oral communication in a Pakistani (EFL) primary classroom (Unpublished master's thesis). The Aga Khan University, Institute for Educational Development, Karachi. 
[29] Gheralis, R.E. (2003). The motivation of English language teachers in Greek Secondary Schools. Unpublished doctoral dissertation, University of Nottingham, Nottingham.

[30] Government of Pakistan [GOP], (2009). National professional standards for teachers in Pakistan. Policy and Planning Wing, Ministry of Education, Islamabad.

[31] Hedges, J. (2002). The importance of posting and interaction with the education bureaucracy in becoming a teacher in Ghana. International Journal of Educational Development, 22, 353 - 66.

[32] Heng, C.S. \& Tan, H. (2006) English for Mathematics and Science: Current Malaysian Language-in-education policies and practices. Language and Education, 20, 306-321.

[33] Hinkin, T.R. \& Schrieshem, C.A. (2004). If you don't hear from me, you know you are doing fine: The effect of management non-response to employee performance. Cornell Hotel and Restaurant Administration Quarterly, 45 (4) 362-372.

[34] Hussin, N.Z. (2000). Motivational factors for foreign language teachers in selected boarding schools in Malaysia, (unpublished thesis). International Islamic University: Malaysia.

[35] Ibrahim, Z.S., Hassali, M.A., Saleem, F., Haq, N.U., Khan, T.M., \& Aljadhey, H. (2013). Perceptions and barriers towards English language proficiency among pharmacy undergraduates at Universiti Sains Malaysia. Pharmacy Education, 13(1), 151156.

[36] Jovchelovich, S., \& Bauer, M.W. (2002). Entrevista Narrativa. In: Bauer MW, Gaskell G. Pesquisa qualitativa com texto, imagem e som: um-manual prático. Petrópolis: Vozes; p. 90-113.

[37] Kennedy, A. (2005). Models of continuing professional development: A framework for analysis. Journal of In - service Education, 31(2), 235 - 250.

[38] Kocabas, I. (2009). The effects of sources of motivation on teachers' motivation levels. Education Journal, 129(4), $724-733$.

[39] Kocabas, I., \& Karakose, T. (2002). School administrator's motivating skill on organisation staff, Firat University Social Sciences Institute Department of Educational Sciences. Unpublished Master Thesis, Elazig.

[40] Kohn, A. (2004). What does it mean to be well educated? Boston: Beacon press.

[41] Lim, H.E., Rich, J. \& Harries, M.N. (2008). Employment Outcomes of Graduates: The Case of Universiti Utara, Malaysia. Asian Economic Journal, 22, 321-341.

[42] Malik, Z.A. (2008). Discovering identities of teachers of English in Pakistan (Unpublished master's thesis). The Aga Khan University, Institute for Educational Development, Karachi.

[43] Momen, H. (2009). Language and multilingual in scientific communication. Singapore Med J. 50(7), 6-54.

[44] Musa, N.C., Koo, Y. L. \& Azman, H. (2012) Exploring English language learning and teaching in Malaysia. GEMA: Online Journal of Language Studies, 12, 35-51.

[45] Muylaert, C.J., Junior, V.S., Gallo, P.R., Neto, M.L.R., \& Reis, A.O.A. (2014). Narrative interviews: An Important resource in qualitative research. Rev Esc Enferm USP, 48(2), 184-189. DOI: 10.1590/S0080-623420140000800027.

[46] Nawab, A. (2012). Is it the way to teach language the way we teach language? English language teaching in rural Pakistan. Academic Research International, 2(2), 696-705.

[47] Njadat, J. (1998). Popular reasons for majoring in English and their motivational implications: Case2. Albasaer, 2(2). 99-122.

[48] Ofoegbu, F.I. (2004). Teacher motivation: A factor for classroom effectiveness and school improvement in Nigeria. College Student Journal, 38(1), 81-89.

[49] Oplatka, I. (2007). The context and profile of teachers in developing countries in the last decade: A revealing discussion for further investigation. International Journal of Educational Management, 21(6), 476 - 490.

[50] Polkinghorne, D.E. (1995). Narrative configuration in qualitative analysis. Qualitative studies in education, 8(2), 5-22.

[51] Praver, M. \& Oga- Baldwin, W. (2008). What motivates language teachers: Investigating work satisfaction and second language pedagogy? Polyglossia, 14, 1-9.

[52] Riessman, C.K. (2008). Narrative methods for the human sciences. London: Sage.

[53] Rogers, B. (2011). Classroom Behaviour: a practical guide to effective teaching behaviour. London: Sage.

[54] Schmit, N. (2002). An introduction to applied linguistics, Oxford University Press, London.

[55] Scott, C, Cox, S., \& Dinham, S. (1999). The occupational motivation, satisfaction and health of health of English school teachers. Educational Psychology, 19, 287-303. http://dx.doi.org/10.1080/0144341990190304.

[56] Shamim, F. (2008). Trends, issues and challenges in English language education in Pakistan. Asia Pacific Journal of Education, $28(3), 235-249$.

[57] Shaw, I., \& Gould, N. (2001). Qualitative research in social work. London, England: Sage Publications.

[58] Shiraz, N., Rashid, M. \& Riaz, A. (2011). The Impact of Re-ward and Recognition Programs on Employee's Motivation and Satisfaction, Interdisciplinary Journal of Contemporary Research in Business, 3(3), 1428-1434.

[59] Shoaib, A. (2004). What motivates and demotivates English teachers in Saudi Arabia: A qualitative perspective (Unpublished doctoral dissertation). Nottingham: University of Nottingham, School of English Studies.

[60] Sparkes, A.C., \& Smith, B. (2014). Qualitative research methods in sport, exercise and health from process to product. Oxford, England: Routledge. http://dx.DOI.org/10.1080/2159676X.2013.796493

[61] Sparkes, A.C., \& Smith, B. (2009). Judging the quality of qualitative inquiry: Criteriology and relativism in action. Psychology of Sport and Exercise, 10, 491-497. http://dx.doi.org/10.1016/j.psychsport.2009.02.006.

[62] Strauss, A., \& Corbin, J. (1998). Basics of qualitative research: Techniques and procedures for developing grounded theory, $2^{\text {nd }}$ (ed.). Thousand Oaks, CA: Sage.

[63] Tracy, S.J. (2010). Qualitative quality: Eight big-tent, criteria for excellent qualitative research. Qualitative Inquiry, 16(10), 837-851. http://dx.doi.org/10.1177/1077800410383121.

[64] Walls, R.T. (1999). Psychological Foundations of Learning. Morgantown, WV: WVU International Center for Disability Information

[65] Walker, R. (2008). 12 Characteristics of an Effective Teacher: a longitudinal, qualitative, quasi-research study on in-service and pre-service teachers"e opinions. Education Horizon 87, 1, 61-68.

[66] Wang, H. (2005). The motivation of public and private school teachers in China. Unpublished MA thesis. 
[67] Wei, L.T. \& Yazdanifard, R. (2014). The impact of Positive Reinforcement on Employees' Performance in Organisations. American Journal of Industrial and Business Management, 4, 9-12. http://dx.doi.org/10.4236/ajibm.2014.41002.

[68] Wosket, V. (1999). Therapeutic use of self: Counselling practice, research and supervision. London: Routledge.

Zafarullah Sahito is a Ph.D-Student at School of Applied Educational Science and Teacher Education, Philosophical Faculty, University of Eastern Finland, Joensuu. Mr. Sahito is a permanent employee (Assistant Professor) at the department of Education, Sukkur IBA University, Sindh, Pakistan. He has over 18 years of teaching, training and research experience at school and university level in Pakistan.

Pertti Vaisanen is working as a Professor and vice Dean at School of Applied Educational Science and Teacher Education, Philosophical Faculty, University of Eastern Finland, Joensuu. Dr. Vaisanen is a Ph.D supervisor of Mr. Zafarullah Sahito, who is working on the project titled: "A Study of Job Satisfaction and the Motivation of Teacher Educator towards Quality Education". He has over 35 years of teaching, training, administrative and research experience in Finland. 